\title{
小児口腔外科手術の周術期管理
}

\author{
中村典史·石畑清秀・村上寿理
}

\section{Perioperative care for pediatric oral surgery}

\author{
NAKAMURA Norifumi · ISHIHATA Kiyohide · MURAKAMI Juri
}

\begin{abstract}
Pediatric oral surgery includes cleft lip and palate repair in infancy, operation for injury of the oral and facial regions, lingual and labial frenectomies, cyst and tumor removal, autogenous bone graft in the alveolar cleft at school age, etc. Additionally, the opportunity in breathing and feeding management of newborn infants with micrognathia may be high for an oral surgeon. A child is not a small-sized adult. The physical structure and physiologic characteristics are different with age, and their behaviors are diverse depending on the development stage in childhood.

In our experience, complications such as upper airway obstruction, upper respiratory infection, urticaria, dehydration, high fever, and decubitus of the lips were observed on perioperative care for pediatric oral surgery during 2004 and 2013. When upper airway obstruction associated with serious micrognathia or pharynx edema due to an injury is suspected, oral surgeons should note and take into consideration that it may develop into a critical state, and act to ensure safe breathing management. In addition, many complications occur in conjunction with intraoperative mouth gag wearing and the operative procedure during cleft palate repair in infancy.

We conclude that it is important to understand the physical structure and physiologic characteristics and the diverse behavioral characteristics depending on their development stage of children and infants, and also to know the possible factors that may cause complications when they engage in pediatric oral surgery.
\end{abstract}

Key words: perioperative care (周術期管理)， pediatric oral surgery（小児口腔外科），breathing management (呼吸管 理), children (小児)

緒

言

小児期に行われる口腔外科手術には, 乳児期に行われる 口唇裂手術, 幼児期に行われる口盖裂手術, 口腔顔面部の 外傷手術, 舌小帯延長術など, さらに, 学童期に顎骨囊胞 や腫瘍摘出術, 顎裂部への自家骨移植術などがある。新生 児期に口腔外科手術がなされることは少ないが，口唇裂・ 口蓋裂児や小嚬症患者の呼吸障害や哺乳を含めた術前管理 に打いて口腔外科医が関与する機会も多い.

一言で小児といっても，大人が単純に小さくなったもの

鹿児島大学大学院医茵学総合研究科顎顔面機能再建学講座 口腔顎顔面外科学分野

(主任：中村典史教授)

Department of Oral and Maxillofacial Surgery, Field of Maxillofacial Rehabilitation, Kagoshiama University Graduate School of Medical and Dental Sciences (Chief: Prof. NAKAMURA Norifumi)
ではなく, 患者の年齢によって, 身体的構造や生理学的特 性, さらに, 発達の違いによる行動特性などが異なってく ることから, 小児口腔外科手術では, 疾患や手術の特徴に 加えて, 小児の発達過程の特徵を十分に理解する必要があ る. 以下に, 小児周術期管理で問題となりやすい呼吸管理, 循環・体液管理, 体温管理, 術創管理等について述べる.

\section{I. 小児の身体的特性}

（1）呼吸系の特徵：小児口腔外科周術期管理で, 最も注 意しなければならないのは, 上気道の狭窄を含めた呼吸障 害と云える。その予防のためには, 小児の呼吸系の特徴を 熟知しておかねばならない（表 1 )。新生児期, 乳児期には 口腔に比し不均衡に大きな舌と下顎の未発達のために容易 に上気道閉塞をきたす。また, 胸骨は柔らかく, 肋骨は水 平に走り, 乳児の呼吸は主に横隔膜により行われる。その 
表 1 小児の呼吸系の特徴

\begin{tabular}{ll}
\hline 生理学的・解剖学的特徴 & 呼吸管理上の問題点 \\
\hline 胸壁筋は未発達, 横隔膜による腹式呼吸, & 一回換気量は少なく, 呼吸回数が多くなる. \\
気道抵抗が高い. & 口呼吸は呼吸不全のサイン, 経鼻チューブ \\
鼻呼吸である. & による換気障害. \\
& 上気道閉塞をきたしやすい. \\
頭部が大きく, 気道が狭い. & 腹部膨満により横隔膜が挙上し, 呼吸障害 \\
腹部が相対的に大きい. & をきたしやすい. \\
& 無理な気管挿管で声門下浮腫を起こす. \\
輪状軟骨部が気管最狭窄部. & \\
気道粘膜は脆弱. & 換気量を増加させる予備力が小さい. \\
肋骨が水平に走り, 胸郭を構築している. & 低酸素血症になりやすい. \\
機能的残気量が小さい. & 咄媄の呼吸確保で, 喉頭展開が難しい. \\
口腔容積に比較して相対的に舌が大きく, \\
扁桃やアデノイドの肥大も多い. \\
\hline
\end{tabular}
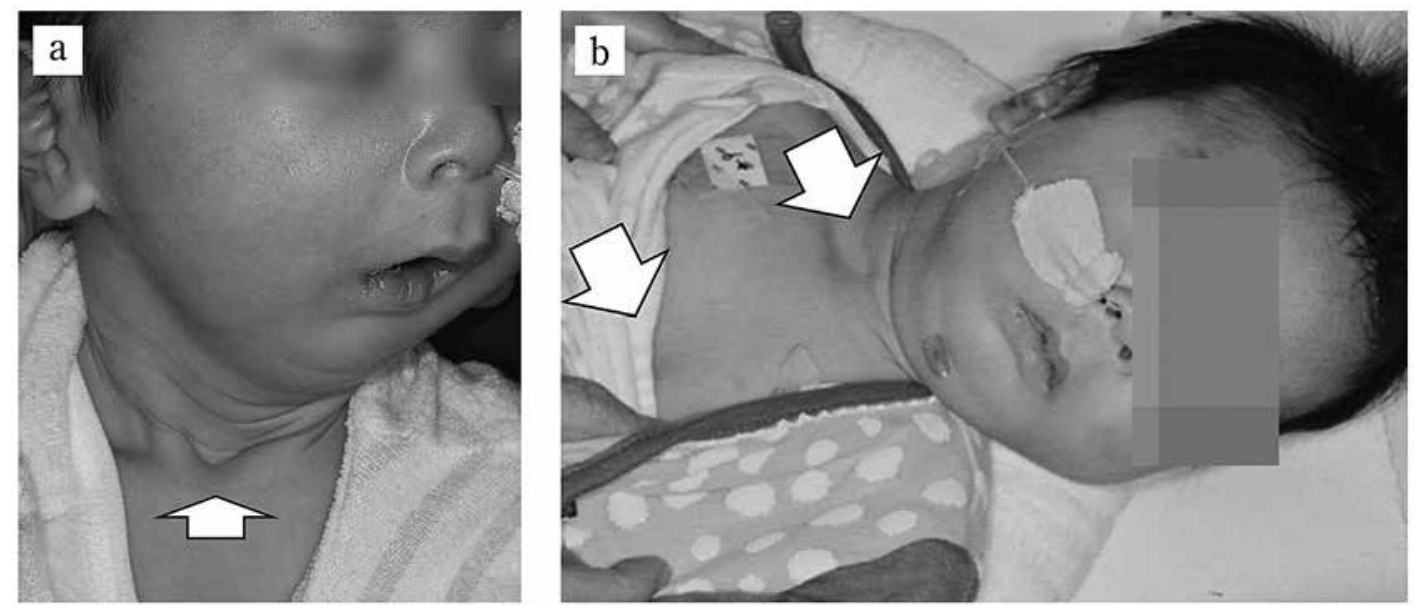

写真 1 小顎症患者の異常呼吸 吸気時の胸骨基部の陥没 (a) と奇異呼吸 (b)

ために一回換気量が少なく，呼吸回数が多くなる．小児は 鼻呼吸であるので, 口呼吸は呼吸不全のサインとされる. また, 肋骨が水平に走り, 胸郭を構築して打り, 機能的残気 量が小さいので，換気量を増加させる予備力が小さく $\left.{ }^{1}\right)$, 低酸素血症になりやすい.

小顎症による気道狭窄：Robin sequence (Pierre Robin syndrome）に代表される小顎症患者では，仰臥位で舌根沈 下によって気道狭窄を生じやすく，吸気時に胸骨基部の陥 没（写真 1a） や奇異呼吸（写真 1b）が観察される。奇異呼 吸とは, 呼吸をする際の肺の収縮・拡張が, 通常と逆の動 きをする呼吸のことである。通常であれば息を吸うと肺は 拡張し，吐けば収縮する。これに対して息を吸ったときに 肺が収縮し, 吐いたときに拡張することを奇異呼吸と呼 ぶ.さらに重篤になると啼泣時にチアノーゼを呈する。こ
のような例では，口蓋裂手術後の上気道閉塞には十分注意 しなければならない。

（2）循環系・体液の特徴：新生児の心筋収縮力は成人に 比べ小さく, 成人の心筋は $60 \%$ が収縮筋として働くが, 新 生児では 30\%しか働かない（表 2)。このために心拍出量は 心拍数に依存する. 小児は成人に比し体重あたりの体表面 積が大きく，基礎代謝熱量が大きい。全体液量は出生時に は体重の $80 \%$ ，3 か月乳児では $70 \%$ を占め，1歳を過ぎる と成人と同じ值 $(60 \%)$ となる。体液分布において細胞外 液量が多く，不感蒸泄量は成人の 2 倍と多い ${ }^{1)}$.

術前・術後水分管理：術前の経口水分摂取制限により乳 幼児は脱水に陷りやすいので, 固形物やミルクは術前 6 時 間前まで, 糖水は 2 時間までとし, 飲水量は $10 \sim 15 \mathrm{~mL} / \mathrm{kg}$, 
表 2 小児の循環系の特徴

\begin{tabular}{ll}
\hline 生理学的・解剖学的特徴 & 呼吸管理上の問題点 \\
\hline 小児の心筋収縮力は, 成人に比べ小さく,成人 & 小児期の心拍出量は心拍数に依存する. \\
の心筋は $60 \%$ 収縮筋として働くが, 新生児 & \\
では $30 \%$ か働かない. & \\
& \\
小児は成人に比べて全体重に打ける体液量が & 飲水制限や術後の疼痛による経口水分攝取 \\
多い. & 不足で容易に脱水に陷りやすい. \\
小児の体液分布は細胞外液が多い不感蒸泄 & \\
は成人の 2 倍多い. & \\
\hline
\end{tabular}

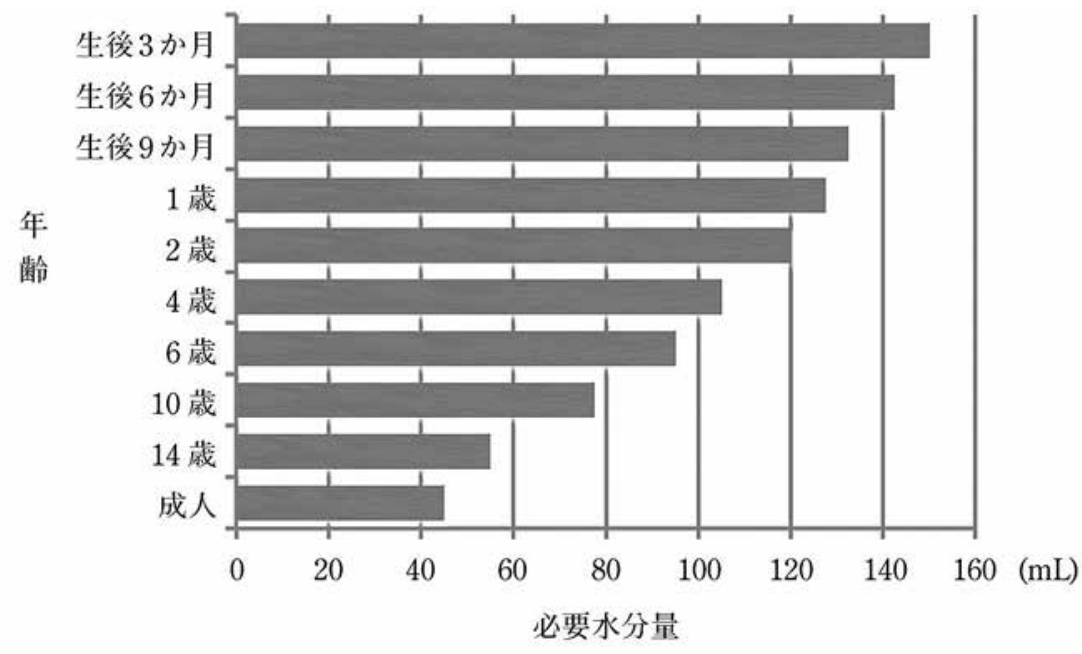

図 1 年齢と必要水分量

(小児 ICU マニュアル 改訂 第 6 版, $2012^{2)}$ より改変引用)

表 3 小児の代謝系の特徴

\begin{tabular}{ll}
\hline 生理学的・解剖学的特徴 & 代謝・体温管理上の問題点 \\
\hline 小児は体重あたりの体表面積が大きく, 基礎 & 飲水制限や術後の疼痛による経口水分摂取 \\
代謝熱量が大きい. & 不足で容易に脱水に陥りやすい. \\
体温調節機構が未発達. & 術中, 術後に低体温, 高熱などの体温異常を \\
& きたしやすい. \\
\hline
\end{tabular}

または上限を $200 \mathrm{~mL}$ とする ${ }^{2)}$ 。術後の水分損取を確実に 確保するために, 点滴の確実な確保 ·固定が重要で, 点滴 詰まりを防ぐために持続点滴ポンプの使用は効果的であ る. 術後の投与水分量は, 1 日水分摂取量を参考に，維持 輸液量十㳖失水分量とする。乳児期：3〜 4 か月頃までは 必要水分量は最大に達し, $140 \sim 160 \mathrm{~mL} / \mathrm{kg} / \mathrm{day}$ が必要と なる ${ }^{2}$ ) (図 1).

（3）代謝系の特徵：小児は体温調節機構が不十分である.
一般に新生児, 乳児は体熱を喪失しやすく, 年長児では逆 に高熱を扢こしやすい(表 3).

手術中は着衣なしで長時間過ごすので, 術中の低体温に は注意する。手術室の室温調節, 体温のモニタリングを行 い, 体温の低下がある場合にはブランケットウォーマーを 用いて体温管理を行う.

（4）体格・皮膚：小児は，成人に比べて柔軟であるが, 体格は小さく, 無理な外力には注意する。また, 絆創膏等 
で容易に皮膚剥離などをきたしやすいので, 粘着テープな どの剥離は丁寧に行う必要がある。

（5）発 達：年齢に応じて病識や治療に対する理解度が 異なる。乳幼児では, 患者の理解度は低いので, 家族に十 分に手術の必要性，内容，術後合併症などを説明し，同意 を得ておく必要がある。年長になるにつれて理解度は高ま るが, 疼痛, 不安, 恐怖によって協力度が一気に下がる.

\section{II. 鹿児島大学病院口腔顎顔面外科における 小児周術期合併症について}

口腔外科における小児手術の周術期合併症について調査 した結果を以下に述べる。 2004 年 1 月 1 日から 2013 年 12 月 31 日までの 10 年間における鹿児島大学口腔㖽顔面外科 の全入院症例は 2,712 例で, そのなかで 15 歳以下の小児 例は 1,037 例 $(38.2 \%)$ を占めていた。同期間における年歯 分布をみると, 0 〜 歳の乳幼児が最も多く, 疾患別には, 口唇口盍裂が 1,037 例中ほぼ 900 例と 9 割近くを占め，そ の他の疾患としては，過剩㐘·埋伏㐘の抜㐘，炎症，外傷， 腫瘍・囊胞が毎年 5 名程度にみられた。

周術期合併症は，カルテに合併症と記載，およびインシ デント報告がなされたものを調查し，17例があった。その 内容を表 4 に示す．年齢では $1 \sim 2$ 歳の幼児が 9 例と最も 多く，次いで $3 \sim 4$ か月の乳児で，その両者が大部分を占め ていた。また，疾患別にみると，全例が口唇裂・蓋裂に 関連していた，周術期合併症の内訳は，挿管後の低酸素症 や喘息様発作, 分泌過多, 術後上気道狭窄など, 呼吸器に トラブルがあったものが 7 例と多くみられた。その他，蕁 麻疹や突発性湿疹が 4 例, 術後脱水や悪性高熱症も 1 例ず
つみられた。また, 下唇の裷瘡, 保護床の脱落といった局 所のトラブルもみられた。 また，合併症には含められてい ないが，入院時の転倒が数件インシデント報告されていた.

以上の結果から，小児口腔外科における周術期合併症の 特徴をまとめると，当科の診療内容の特徴が多少反映され ているものの，口唇裂・口蓋裂に関連するものが多いこと， 0 ～歳までの低年歯児に多くみられること，さらに，周 術期合併症は呼吸障害 (上気道閉塞), 上気道感染, 脱水, 高熱，術後の口唇裷瘡，皮膚炎などがあるといえる。

\section{III. 小児口腔外科における周術期管理の実際}

すでに，口唇裂・口蓋裂では，周術期合併症が起こり やすいことを述べた。表 5 には，合併症が多い理由となる

表 4 鹿児島大学口腔顎顔面外科に打ける小児周術期合併症 (鹿児島大学病院口腔顎顔面外科 $2004.4 \sim 2013.3$ )

\begin{tabular}{lccc}
\hline & $3 \sim 4$ か月 & $1 \sim 2$ 歳 & 7 歳以上 \\
\hline 挿管後低酸素血症 & 2 & 2 & \\
喘息様発作 & 1 & 1 & \\
術後上気道狭窄 & & 1 & \\
䕒麻疹·突発性湿疹 & 2 & 2 & 1 \\
脱 水 & & 1 & 1 \\
高 熱 (悪性高熱症) & & & 1 \\
口唇裖創性潰瘍 & & 1 & 3 \\
その他 & & 9 & 1 \\
\hline 計 & 5 &
\end{tabular}

表 5 口唇裂・口蓋裂手術で合併症が多い理由

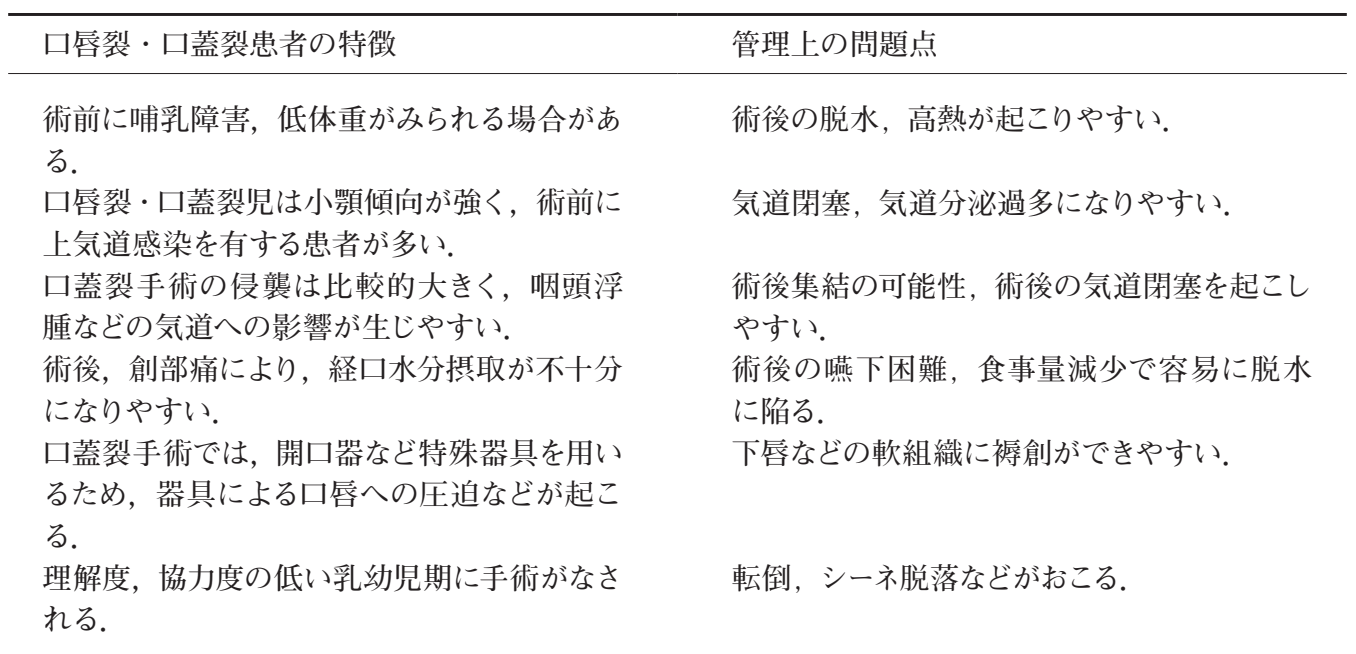


口唇裂・蓋裂患者の特徴とそれに伴う管理上の注意点を 挙げている，以下に，これらのことを踏まえて，術前・術 中・術後の流れに沿って, 小児口腔外科手術の周術期管理 の注意点について述べる.

\section{1. 術前管理}

全身合併症の精査：出生時，生後の定期検診で全身合併 症が指摘される場合には，必ず専門医の対診を受け，口腔 外科手術の適応と時期について協議する必要がある．基本 的に，口唇裂・口蓋裂などの先天異常に対する口腔外科手 術は緊急処置ではないので，合併症の治療が優先される．

顔面外傷の患者で頭部外傷が否定できない場合は，脳外 科医に対診して，受傷時の頭部外傷がないことを確認した 後に口腔外科処置を開始する。

哺乳のチェック：新生児，乳児の場合，術前に患者の栄 養状態を把握することは重要である。栄養状態は体重増加 と哺乳量で評価する。哺乳量は，一回哺乳量, 哺乳回数か ら一日哺乳量を計算する。母子手帳に記載された出生時体 重ならびに，その後の身長・体重変化を測定し，日本人乳 児身体発育曲線（図 2. 母子手帳に性別に記載）と比較す る，生後，標準体重範囲内で体重が推移する場合には，哺 乳量は良好と判断されるが，徐々に標準曲線から離れるよ うであれば，生命予後を危うくするといわれるので積極的 な哺乳指導に取り組み，同時に小児科医へ対診する。

口蓋裂を伴う場合には，直母乳からの哺乳では有効な哺 乳量を得にくいので，搾乳を勧める。表 6 に口蓋裂に開発 された専用哺乳瓶と乳首の特徵を示す。口腔咽頭の発達が 悪く，哺乳力が弱い場合には，母親が補助できる哺乳瓶
（ハバーマン型）を用いた哺乳指導が有効である（写真 2a）。幅広の唇䫈口蓋裂でミルクの鼻漏出が多い場合には, ホッッ型口蓋床の適応となる (写真 $2 b)$ ，未熟児で，自力 哺乳力が弱い場合には, 小児科医と相談し, 哺乳力が増す までチューブ栄養の適応となる場合もある。

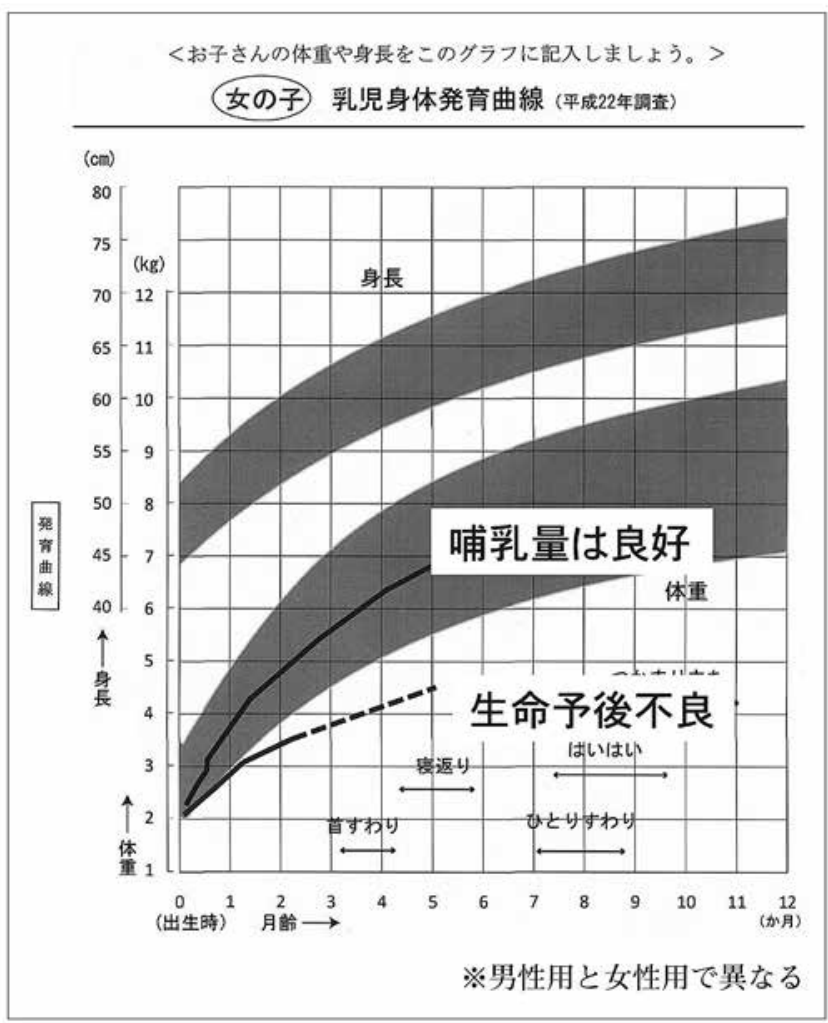

図 2 乳児身体発育曲線（女児）を用いた哺乳状態の評価 標準曲線から外れると生命予後が悪くなるとされる.

表 6 口蓋裂用哺乳瓶 (乳首) の特徵

\begin{tabular}{|c|c|c|c|c|}
\hline 会社 / 名前 & メデラ / ハバーマン型 & ピジョン / P 型 & NUK / 口蓋裂用 & チュチュ / 口蓋裂用 \\
\hline 特 性 & $\begin{array}{l}\text { 口蓋裂を含む哺乳 } \\
\text { 障害を含むすべて } \\
\text { の患児対応. } \\
\text { 乳量増減できる. }\end{array}$ & $\begin{array}{l}\text { 乳頭部が大きく, } \\
\text { 口蓋裂に密着. } \\
\text { 押しつぶす力で } \\
\text { 哺乳可能. }\end{array}$ & $\begin{array}{l}\text { 乳首部が平たく大 } \\
\text { きく, 裂内に落ち } \\
\text { 込みを防ぎ口蓋を } \\
\text { 広く被う. }\end{array}$ & $\begin{array}{l}\text { 乳頭部の上側が平 } \\
\text { 坦 (扁平). } \\
\text { 口蓋床をつけた患 } \\
\text { 児用に開発. }\end{array}$ \\
\hline 乳 孔 & スリーカット & クロスカット & 自分で開ける & クロスカット \\
\hline 乳頭の大きさ & & 直径 $16 \mathrm{~mm}$ & 横径 29mm & 平面部 13mm \\
\hline 素 材 & シリコンゴム & イソプレンゴム & 天然ゴム & シリコンゴム \\
\hline 逆流防止弁 & あり & あり & な し & な し \\
\hline 専用哺乳瓶 & あ り & なし & なし & なし \\
\hline 外部からの乳量調節 & 3 タイプに増減できる & 増量のみ & な し & な し \\
\hline
\end{tabular}



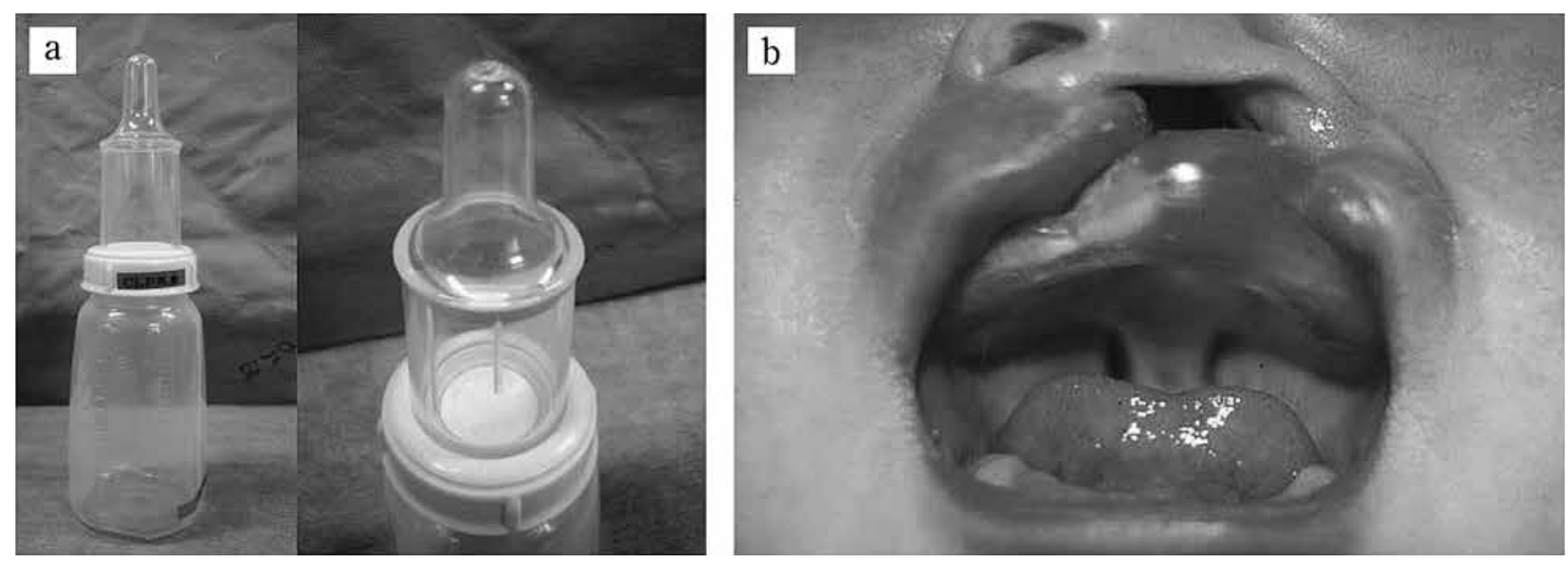

写真 2 哺乳力の弱い乳児のための哺乳瓶 (a) と ホッツ型口蓋床 (b)

呼吸のチェック：小顎症を伴う口蓋裂児，咽頭部に及ぶ 炎症，下顎骨の骨折では，舌根沈下，咽頭部の浮腫のた めに上気道狭窄をきたすことがある，前述のごとく Robin sequence などの小顎症患者では，仰臥位にすると舌根沈 下により, 吸気時に胸部が沈下する奇異呼吸が観察される. さらに重度の場合には啼泣時にチアノーゼを呈する。外傷 等で咽頭浮腫による気道狭窄が疑われる場合には, 速やか にCT 検査等で気道の狭窄程度を精査し, 気道確保処置が とられなければならない。

呼吸障害がみられる場合に，口腔外科医に舌牽引術の適 応を相談されることが多い。下嘖角部を前方に引き出して 呼吸状況が改善するようであれば，舌根沈下による気道閉 塞が疑われる。重度な呼吸障害がある場合には，小児科医 に対診し, 舌前方牽引手術，あるいは気管切開の適応を協 議しなければならない場合もある。舌牽引術では, 舌下面 に横切開を加え, 下唇粘膜部の横切開創と縫合固定する が，緊張が強い場合には容易に脱離しやすい。緊張が強い 場合は，舌根部に大きく絹糸，またはナイロン糸を影けて， その糸を下顎骨に囲繞結紮した糸に縫合固定する方法がよ (1) 3,4$)$.

上気道感染の精査：小児の場合，上気道感染，いわゆる かぜ症候群にとくに注意する。上気道感染があると, 麻酔 中に喉頭痤攣や気管支喘息を起こしやすく, 術後の低酸素 血症や無気肺を生じやすい。 上気道感染後の気道の過敏性 は数週間持続するので, $3 \sim 4$ 週間手術を延期する。また， 術前の問診では家族や兄弟の通う幼稚園などでウィルス感 染が流行っていないかを尋ねる必要がある。死菌ワクチン 接種を受けた場合は，1週間は手術を避け，生ワクチン接 種を受けている場合は前後 3 週間の手術を避ける。当科で は，入院前のチェックのために，患児，兄弟，両親，およ びその周辺者（保育園や幼稚園など）のウィルス感染の有
無のチェックシートを作成し，手術前後のウィルス疾患の 発症を予防している。

手術前の準備: 入院後, 低年歯児は居住環境が変わると 緊張で発熱する場合が多い。乳幼児では家族同伴での入院 が望ましく,リラックスした環境作りが必要である。また， 一般に病室は乾燥しやすいので, 室温, 湿度を適切に維持 することが望ましい。

\section{2 . 術中管理}

基本的には，麻酔科による全身管理が重要項目であるが， ここでは，小児患者で特徴的に注意しなければならないこ とを記載する。

経口水分摂取制限：術前の経口水分㩒取制限については, 乳幼児は脱水に陥りやすいので, 固形物やミルクは術前 6 時間前まで, 等水は 2 時間までとし, 量は, $10 〜 15 \mathrm{~mL} / \mathrm{kg}$, または上限を $200 \mathrm{~mL}$ とする ${ }^{2}$ ．

麻酔中の注意点：気管内挿管は麻酔科医によって行われ るが，一般に乳幼児にはカフなしの挿管チューブ，学童以 上ではカフ付きチューブが用いられる，小児の気管内径は 狭いので, 挿入時, 抵抗が強い挿管チューブは避けられる べきである。一方，挿管チューブが小さすぎる場合は，麻 酔ガスの漏れ, 口腔内の血液の気管内への流入の問題が生 じるので, 麻酔科医と相談して, 咽頭パックガーゼの挿入 が必要となる。

口蓋裂手術中の注意事項：口蓋裂手術では, ディングマ ン型開口器を用いて, 開口させた状態で手術がなされる (写真 3). この時, 舌圧子と下顎前菊による挿管チューブ の屈曲 (圧平) が原因となる換気障害, および, 開口時に 舌圧子がチューブを押し下げることによる片肺挿管による 低酸素症は, 口蓋裂手術の最も危険な合併症の 1 つである. 術者は, 常にチューブの深さと術野の血液の色に注意し， 

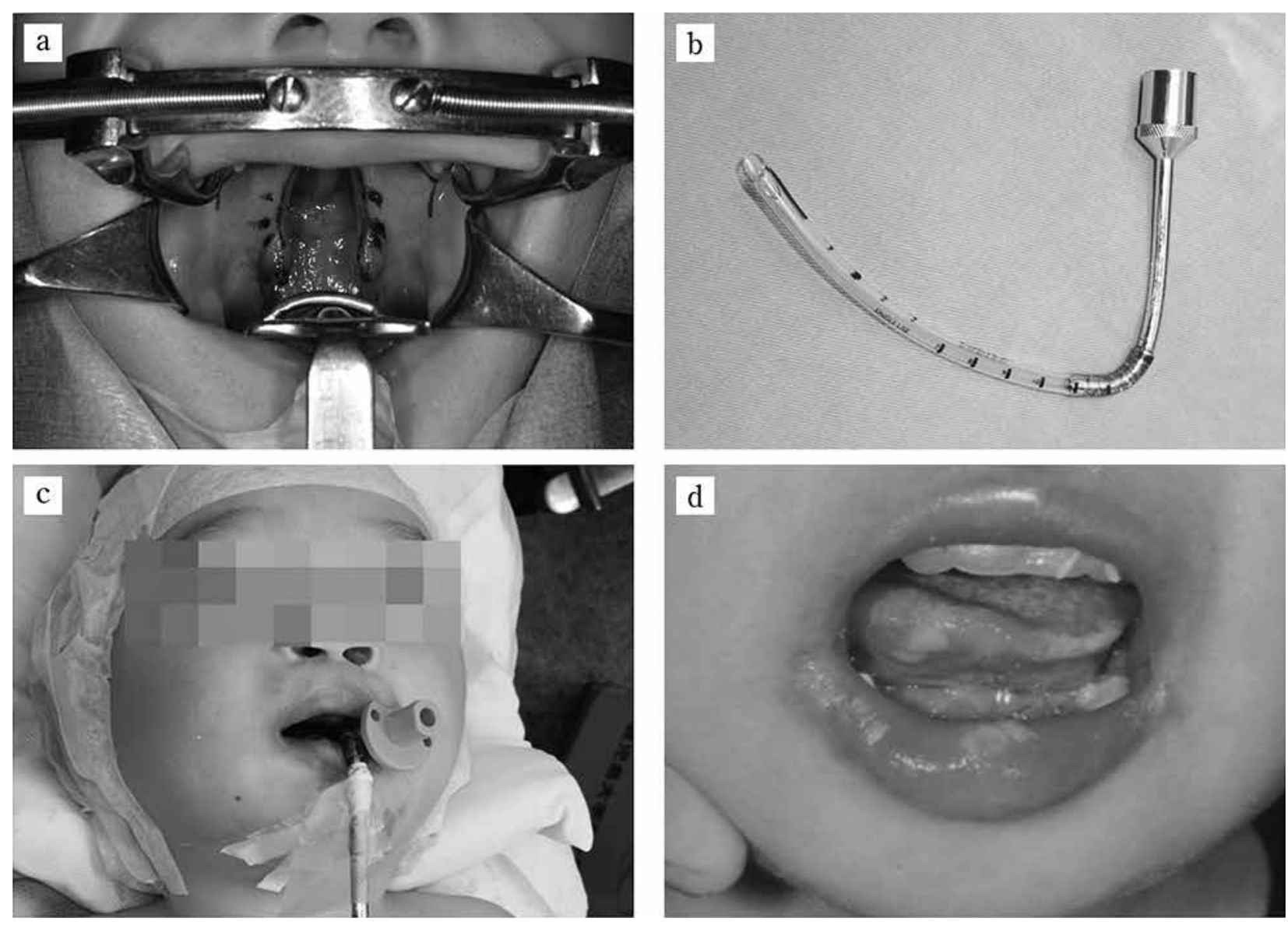

写真 3 口蓋裂手術の術中写真と口唇部の袝瘡

ディングマン型開口器の装着状態 (a) 舌圧子による挿管チューブの圧平を防止するための金属チューブ (b) バイトブロックによるロ唇の刺激 (c) 口蓋裂術後の口唇, 口角部の裷瘡 (d)

麻酔科医にディングマン型開口器装着によって換気が障害 されていないかを確認する。もし，舌圧子と下顎前㐘によ る挿管チューブの圧平がみられる場合には, 舌圧子と下顎 前柬切縁の間に小ガーゼを挿入するか，あるいは舌圧子に よって圧迫される部分を金属チューブに置き換えるなどの 配慮が必要である (写真 3 ).

口盍裂手術でディングマン型開口器を用いて開口させる 場合，舌圧子，リトラクターなどで圧迫して，上下唇や口 角を損傷する場合がある。術者は軟組織を厤迫していない ことに留意を払いながら手術をするとともに，2 時間置き に開口器を解除して, 裤瘡を作らないように注意する必要 がある。

手術終了時の注意事項：小児では，覚醒後の再処置が困 難であるので, 成人とは違って, 手術終了時の確認は重要 である。とくに注意すべきは，口腔内からの確実な止血の 確認, 創部のドレッシングや保護シーネの確実な装着, さ らに, 輸液ルートの確保は重要で, 覚醒前に点滴チューブ の固定を確認したうえで手術終了とする。

\section{3 . 術後管理}

呼吸の管理 : 術後は, 麻酔薬の効果の遷延, 筋弛緩薬の 遷延, 口腔外科手術による咽頭部の浮腫による気道の狭窄 による呼吸抑制が起こり得る。口腔外科手術による咽頭部 の浮腫による気道の狭窄は, 即効性ステロイド薬の投与に より浮腫の防止を行うとともに酸素飽和度をモニターする。

口蓋裂術後の最も重大な合併症は, 後方移動した軟口蓋 や咽頭の浮腫による気道狭窄である。すでに抜管された後 の気道閉塞は危機的な状態に陥りやすい，気道の狭窄が懸 念される場合には, 経鼻エアウェイを使用して, 気道を確 保することが重要である。一般に, 術後 2,3 日で咽頭浮 腫は改善し, 気道の確保が得られる場合もあるが, 小顎症 の患者では，長期間を要する場合もある。したがって，小 顎症患者に打いては, 術後 NICU 管理が望ましく, 浮腫が なく，気道が十分にあることを確認した後に，気管内挿管 チューブを抜去することが安全である.

経口水分摂取：麻酔から十分覚醒して, 有効な腸管蠕動 が得られたら経口水分摂取を開始する。口腔外科手術では 

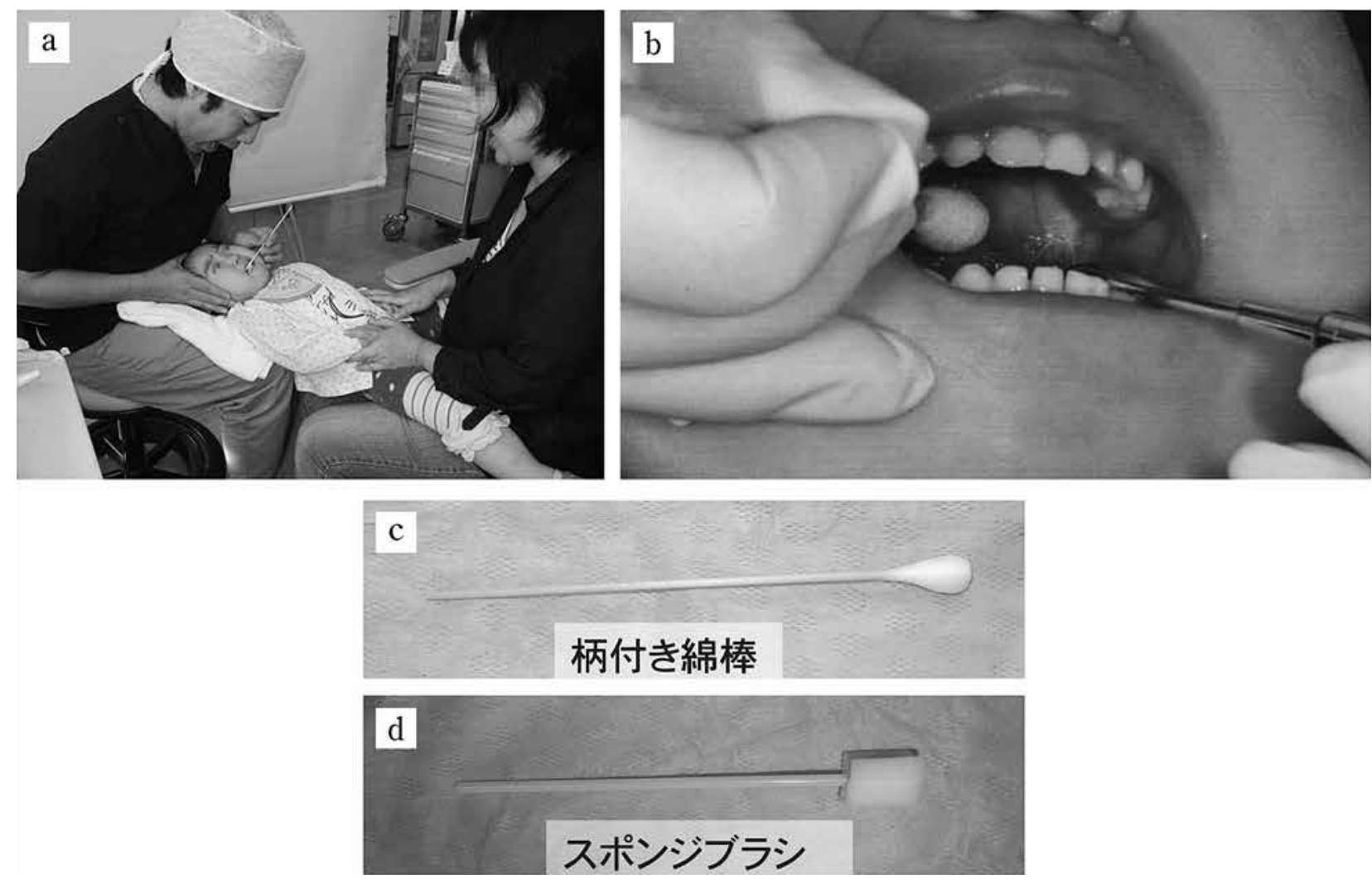

写真 4 乳児の口腔内手術創清拭と柄付きの綿棒等による䛊嚥防止

乳児の口腔内手術創清拭の体位 (a) 柄付きの綿棒による誤嚥防止 (b) 柄付きの綿棒 (c) スポンジブラシ (d)

手術終了後, 3 時間程度となる。経口掑取は，嘔吐が起こる ことを考虑して, 水, 糖水などから開始する. 小児は水分 掑取不足で容易に脱水に陥りやすいので，水分摂取を確実 に確保するために, 輸液ルートに確実な確保・固定が重要 である，点滴部位は屈曲部を避け，固定用シーネを用いて， 離脱しないように確実に固定するとともに, 輸液ポンプを 用いて点滴チューブの詰まりを防ぐことなどを配虑する。

創部の清掃：小児の口腔内の手術創の管理は，患者が非 協力では口を開けないために，苦労する場合がある。小児 の周術期管理のなかで，異物の䛊嚥による㗧息は，とくに 注意が払われなければならない事項である。当科では，清 拭用の綿球の咽頭への落下を防止するために, 口腔内清拭 は柄のついた綿棒やスポンジブラシを使用することを原則 としており（写真 4), 口唇部の創の清拭に打いても, 反対 の人差し指で口裂を塞ぎながら行うように配慮している.

低年齢児の抜系：成人と違って，低年齢児の抜糸は協力 が得られず，困難な場合が多い， 口腔内の創に対しては， 吸収糸を用いて縫合し，抜糸を不要にして打くことがよい． 一方，口唇裂手術など皮膚の縫合糸は丁寧に抜糸しなけれ ばならない，低年齢児の抜糸に全身麻酔を使用する施設も あるが, 全身麻酔の繰り返しが生体に与える悪影響を考え
ると, 鎮静薬の内服で睡眠下に抜糸するのがよいと考えら れる.

当科では, 口唇裂術後 (生後 3 か月) では, トリクロリー ルシロップ $0.8 \mathrm{~mL} / \mathrm{kg}$ を内服させ, 鎮静下に抜系を行って いる。この場合, 嘔吐を避けなければならないので, 最低 2 時間の経口水分摂取制限をした後に, 鎮静薬の投与を行 うことが重要である。

\section{4. その他の管理上の注意点}

小児は, 年齢に応じて病識や治療に対する理解度が異な る。乳幼児は理解度が低いので, 家族に十分に手術の必要 性, 具体的な内容, 術後合併症を説明し, 同意を得る必要 がある．同時に，身体抑制が必要な場合には身体抑制の同 意書を取得しておくことも重要である。年長になるにつれ 理解度は高まるが, 疼痛, 不安, 恐怖によって協力度が著 しく低下する，患者なコミュニケーションをとって，難し い言葉や不安に繋がる言葉を避け，分かりやすく説明する ことに留意すべきである。

全身疾患を有する小児患者，とくに化学療法を受ける患 者に対する口腔ケアについては, 保湿・保清の維持, 粘膜 保護，疼痛緩和を基本として対処する。実際には，患児の 
口腔に適した大きさのスポンジブラシで, 痂疲や舌苔を除 去し, 口唇煩粘膜に適宜ワセリンを塗布して保護すること が多い。唾液の分泌が多い患児には, 吸引チューブ付き㐘 ブラシを用いて，痛がらせないように，最大限の注意を図 ることが重要である。さらに粘膜の状態が悪い場合は必要 以上に刷掃しない方がよく，必要であれば，鎮静下で口 腔ケアを行うことなども検討する。口腔ケアを乱暴に感じ るという家族も少なくないことを念頭に拉き，家族とのコ ミュニケーションを良好に築きながら，進めることが望ま れる。

\section{結語}

小児口腔外科周術期管理で, 最も重要なことは, 気道の 確保を含めた安全な呼吸管理と言っても過言ではない。と くに，小顎症患者や外傷等で咽頭浮腫による上気道狭窄が 疑われる場合は，致死的な状態に陥る可能性があることを 常に念頭において, 安全な気道の確保に務める必要がある. その他, 小児の口腔外科周術期管理では, 上気道感染, 脱 水, 高熱, 術後の口唇褾瘡などの合併症が起こりやすく, 小児の身体的構造や生理学的特性, さらに，発達の違いに よる多様な行動特定を十分に理解することが重要である.
また, 乳幼児期に手術を受ける口唇裂・口盍裂手術では， 術中の開口器装着, ならびに手術操作に関連した合併症が 多いことから, 合併症につながる要因を充分に熟知して手 術に望むことが重要である。

本内容は, 2015 年 2 月 28 日, 3 月 1 日（於東京）, および 2015 年 7 月 25 26 日 (於京都) に開催された第 43 回 (公社) 日本口腔外科学会教育研修会, 口腔四学会合同研修会「口腔 外科の周術期管理を考える」で発表した。

本論文に関して，開示すべき利益相反状態はない.

\section{引用 文 献}

1）正木英二：小児の麻酔管理，金子 譲，福島和昭, 他 編著; 柬科麻酔学. 第 7 版, 医柬薬出版, 東京, 2015, 437-447 頁.

2 ) 志馬伸朗, 橋本 悟, 他編著: 小児 ICU マニュアル. 改訂第 6 版, 永井書店, 大阪, 2012, 144-178 頁.

3 ) Oeconomopoulos CT : The value of glossopexy in Pierre-Robin Sequence. New Eng J Med 23: 12671268, 1960.

4 ) 杉原一正, 松井竜太郎, 他: 舌前方衰引固定術を行っ た Pierre-Robin 症候群の 1 例。 小児口外 8: 34-38, 1998. 